\title{
Tales of Policy Estrangement: Non-Governmental Policy Work and Capacity in Three Canadian Provinces
}

\author{
Bryan Evans \\ Ryerson University \\ Adam Wellstead \\ Michigan Technological University
}

\begin{abstract}
Recently, there have been a number of Canadian-based studies of federal and provincial government policy workers. One key theme across all of these studies is the importance of well-established networks outside of government. However, these studies have demonstrated that government policy workers interact very infrequently outside the comfort of their own department cubicles. This stands in contrast to the considerable literature on new public governance theory, which suggests that non-governmental organizations (NGOs), including nonprofit groups, should, and do, play an important role in shaping public policy. This article provides some insights into this question and identifies where NGO-government interaction does exist. The descriptive results from a survey of non-governmental organization policy workers across four fields (environment, health, labour, and immigration) in three Canadian provinces (British Columbia, Saskatchewan, and Ontario) clearly illustrate the limitations, at all levels, on interaction between NGO groups and government officials. The article argues that this does not disprove the basic tenet of new governance theory-that non-state actors are engaged, to some degree, in the policy process. The article examines the results of an ordinary least squares (OLS) regression model to determine what factors shape and drive NGO interaction with government.
\end{abstract}

\section{RÉSUMÉ}

Depuis peu, bon nombre d'études canadiennes sont apparues sur les stratèges des gouvernements fédéral et provinciaux. Un thème clé dans ces études est l'importance de maintenir des réseaux viables au-delà $d u$ gouvernement. Pourtant, selon diverses études, les stratèges gouvernementaux interagissent très peu au-delà de leurs bureaux à cloisons. Cette situation ne reflète pas l'approche recommandée dans les nombreux écrits recourant à la théorie de la nouvelle gouvernance publique. Celle-ci recommande aux organisations nongouvernementales (ONG), y compris aux groupes sans but lucratif, de jouer un rôle plus important dans la formulation des politiques publiques. Cet article explore cette question et identifie les domaines où existent des interactions entre ONG et gouvernements. Les résultats d'un sondage de stratèges d'ONG dans quatre 
domaines (environnement, santé, travail et immigration) dans trois provinces canadiennes (ColombieBritannique, Saskatchewan et Ontario) illustrent clairement les contraintes, à tous les niveaux, sur les interactions entre ONG et gouvernements. L'article soutient que cette situation ne contredit pas le principe fondamental de la théorie de la nouvelle gouvernance publique, à savoir que des acteurs non gouvernementaux s'engagent effectivement, jusqu'à un certain point, dans la formulation de politiques. Cet article examine en outre les résultats de l'application d'une méthode des moindres carrés pour déterminer quels sont les facteurs qui influencent et motivent les interactions entre ONG et gouvernements.

Keywords / Mots clés : Policy engagement; Policy workers; Non-governmental organizations; New public governance / Engagement politique; Stratèges; Organisations non-gouvernementales; Nouvelle gouvernance publique

\section{INTRODUCTION}

This article is based on a survey of non-governmental (NGO) policy workers in the Canadian provinces of Ontario, British Columbia, and Saskatchewan, conducted in early 2012. Our interest in NGO policy workers emerges from the body of new governance literature, which suggests that a substantively greater role for nongovernment actors in the policy process has emerged over the past three decades. Using an ordinary least squares (OLS) regression model, this article identifies various factors that appear to drive NGO engagement with government policy. Our overarching conclusion is that provincial NGO policy actors are relatively active participants in service delivery but less so in policy formulation. The data suggest that key decisions about policy design are made prior to NGO engagement. Following a review of the literature on governance, new public governance theory, and empirical policy work-studies. The second section outlines six research hypotheses designed to explore the drivers of NGO interaction with provincial agencies. The third section details the research methods and data collection process. The fourth section outlines the data collected and the OLS regression multivariate analysis we conducted based on descriptive variables. In the final sections, we test our research hypotheses using the descriptive results of the OLS analysis, and, finally, we discuss policy implications and raise questions for further investigation.

\section{LITERATURE REVIEW: QUESTIONING THE NEW GOVERNANCE LITERATURE}

In Canada, several studies have examined policy capacity within Canada's federal and provincial governments. The studies consist of everything from expert panels and reports (Fellegi, 1996; Peters, 1996; Savoie, 2003), to reflections of senior officials (Anderson, 1996; Rasmussen, 1999; Voyer, 2007), to survey results (Bernier \& Howlett, 2011; Howlett, 2009; Howlett \& Wellstead, 2012; Wellstead \& Stedman, 2011; Wellstead, Stedman, \& Howlett, 2011). This recent production of quantitative research delves into the nitty-gritty "who and how" details of front line policy work. Given the important policy fields administered by the Canadian provinces, either in whole or to a significant degree (health, education, labour market, immigration settlement, environment), further research at this level is required. Howlett (2009) places the NGO dimension (and this includes business, labour, and civil society organizations) on the research agenda when he asks, "What do policy analysts actually do in contemporary governmental and non-governmental organizations" (pp. 163-164)? He further urges students of 


\section{Evans \& Wellstead (2014)}

public policy and management to ask if the training and resourcing of policy workers is adequate up to the task. Taking Howlett's (2009) suggestions for additional research seriously, this work explores how governmental and NGO policy workers engage with one another. The new governance literature suggests that "policies can no longer be struck in isolation in government" (Lindquist, 2009, p. 9). The research in this article seeks to establish to what extent this has been put into practice.

In 1996, R.A.W. Rhodes declared that networks had joined markets and hierarchies as one mode of "governing structure" (p. 653). Through the 1980s, in the case of Britain, a decentring of the state in the policy process was observed, whereby policy outcomes were no longer "the product of actions by central government. The centre may pass a law but subsequently it interacts with local government, health authorities, the voluntary sector, the private sector and, in turn, they interact with one another" (p. 657). This led Rhodes to conclude that we now inhabit a "centreless society," wherein it is the task of the "polycentric state" to "enable socio-political interactions" (p. 657). Thus, we have an image of an interactive policy-making process in which the government engages with relevant non-governmental policy actors. Political steering is carried out through networks built of "overlapping roles of political and societal actors" and characterized by "low institutionalization and a general blurring of bureaucratic demarcations" (Koch, 2013, pp. 397-398). Optimally, non-governmental actors enter at an early stage in the process, so as to have a meaningful role in shaping the final policy product (Edelenbos, 1999). This plurilateral policy process, engaging a broad spectrum of non-governmental actors, is understood in the literature to be a positive development in the realm of policy praxis (van der Heijden, 2013), supporting the widely held view that "the more new governance, the better" (Solomon, 2008, p. 862) the policy outcome.

The core characteristics of new governance are collaboration and deliberation (Gunningham, 2009; Hoffman, 2011; Karkainen, 2004; Lobel, 2004; Solomon, 2008). In concrete terms, collaboration in the new governance sense refers to bringing "multiple stakeholders together in common forums with public agencies to engage in consensus-oriented decision making" (Ansell \& Gash, 2008, p. 543). Through collaboration, a policy solution can be negotiated for problems too complex to be adequately dealt with through more traditional processes such as by the initiative of a single government department. The closely allied concept of deliberation refers to the process through which all stakeholders, not just government decision-makers or elite stakeholders, are given a role in the policy process (Heijden, 2013; NeJaime, 2009). A new paradigm of power sharing thus emerges (Ansell \& Gash, 2008). What is distinctive in this paradigm is that "a wider variety of non-governmental organizations are becoming active participants in governing" (Bevir, 2011, p. 2). The proponents of new governance understand this as expressing a "change in the nature of the meaning of government" (Bevir \& Rhodes, 2003, p. 4). While this view expresses the new governance orthodoxy, the field is not without a serious body of emerging critical perspectives grounded in empirical research (Bode, 2006; Goetz, 2008; Hoogh \& Marks, 2003; Janicke \& Jorgens, 2006). The central question to be answered in the governance debate is, as Capano (2011) puts it, "What role do governments now actually play" (p. 1623)?

The new governance model of policy construction is contested. The deliberative process at the centre of new governance theory assumes a fairly even distribution of political and other resources among non-governmental policy actors; the theory fails to acknowledge that in this framework, "talk is disconnected from power" (Noveck, 2011, p. 89). In other words, if policy is an expression of power relations in society, and if that power is unevenly 


\section{Evans \& Wellstead (2014)}

distributed, can one assume that increased inclusivity will free the policy making process from this constraint? We need to question the extent to which non-governmental stakeholder participation is meaningful (Ford \& Condon, 2011). Moreover, non-governmental organizations themselves reflect this uneven distribution of power. Given that they represent the diverse interests of larger society, not all NGOs have equal access to resources or to political power. Weaker, less politically recognized NGOs, such as those advocating redistributive policy, antipoverty policy, or labour reform, may not be included in government processes, or consultations with them may be perfunctory. The inequality characterizing wider society is often simply reproduced within the open and pluralized new governance policy process, as insiders with significant resources and political links to the state tend to dominate and realize their specific policy goals (Ansell \& Gash, 2008; Mol, 2007). Empirical studies of deliberative processes have found that they often fail to be completely inclusive and that they minimize or ignore the proposals of policy actors who have "outsider" status (van der Heijden \& Ten Heuvelhof, 2012; Eversole, 2010).

Consequently, the core thesis underpinning new governance theory, which implies that government is losing its pre-eminent role at the centre of the policy process and that state-dominated hierarchy is giving way to multiactor plurilateralism, is contested and in some cases rejected (Heritier \& Lehmkuhl, 2008; Hill \& Lynn, 2005; Howlett, Rayner \& Tollefson, 2009). A counter-narrative contends that what "appears to be a shift away from government may turn out to be a path towards government" (Goetz, 2008, p. 272). Capano's (2011) study of the shifting governance framework in the higher education systems of four European countries finds the state to be very much engaged in steering the sector in each case, albeit unevenly and from a distance. Capano finds no pure governance type but rather a "hybridization" of the governance mode (p. 1639). Koch's (2013) analysis of the integration of four public transport systems in Switzerland leads to his observation, at least in terms of the cases studied, that network governance constitutes one step within a process of governance reform which is moving toward a more hierarchical and institutionalized form (p. 418). In other words, the loose governance framework becomes governmentalized, namely institutionalized in government institutions. Howlett, Rayner, and Tollefson's (2009) study of forest planning governance in British Columbia examines a case in which new policy actors successfully shaped both policy processes and outcomes-yet even so, they question the overarching new governance paradigm (p. 384). Their study finds no straightforward shift in governance, but rather that the "reality of BC forest policy is a great deal messier than implied" (p. 384) by the incorporation of new actors in the policy process. They go even further, asking "whether any newly emerging mode of governance is any more effective or legitimate than the 'old' government model" (p. 384).

The Canadian cases studied here tend to offer a complex, perhaps contradictory, perspective on NGOgovernment engagement. Indeed, NGO respondents provide evidence of "high expectations," even confidence, with respect to their own capacity to make policy, but the opportunities for them to actually engage with government are less evident. For practitioners, we offer insights as to which attributes of NGOs lead to greater engagement with government decision-makers.

Some studies and commentary overviewed here are specifically concerned with the policy role of Canadian NGOs in light of new governance challenges. Phillips (2007) was perhaps among the first to question the new governance thesis within the context of Canadian public policy making. She questions the categorical assertion that new governance "has systematized and institutionalized" the involvement of non-governmental actors in the 


\section{Evans \& Wellstead (2014)}

policy process, arguing that "we know relatively little about how and to what extent such groups conduct policy analysis in the current context, how they use it to exert policy influence, and to what end" (Phillips, 2007, p. 497). She poses several basic questions requiring further empirical research:

Have civil society organizations adopted policy styles that are compatible with a supposedly more open, inclusive, and participatory system of governance? Are they effective participants in policy networks and in shaping Canadian public policy? If not, why not? Are policy processes in Canada actually as open and as participatory as this model of "governance" suggests? (p. 497)

As other Canadian studies considered here note, a key limitation is that "few voluntary sector organizations ... have the policy capacity to participate effectively" (Phillips, 2007, p. 498). Carter (2011) reports descriptive results from a 2005 survey of "several thousand" nonprofit groups and a 2007 survey of the voluntary sector as part of her evaluation of the federal government's Voluntary Sector Initiative. Her key finding was that fewer than 25 percent of nonprofit organizations participated directly in public policy processes. This degree of nonparticipation is not a function of disinterest, but of a lack of capacity (Carter, 2011, p. 430-431). Carter notes, however, that nonprofit organizations are often involved in the implementation of public policy regardless of whether they have been active participants in the agenda setting or design phase of the process (p. 432). Similarly, Mulholland (2010) points out that non-governmental policy capacity has eroded as a consequence of government funding cuts, the Great Recession, and the advocacy chill, among other factors (p. 141). One result has been the emergence of "communities of purpose," which Mulholland (2010) defines as "relatively informal collaborations of organizations and individuals, united in support of a shared aspiration or goal, with a strong innovation focus, and highly skilled at building sectoral and cross-sectoral policy consensus and using this to influence policy" (p. 141).

From an entirely different perspective, Laforest and Orsini (2005) highlight the increasing importance of evidence-based policy work and its effect on nonprofit organizations. Their thesis contends that government for more evidence-based policy research produced by civil society organizations is displacing NGOs from their prior central role as representatives of their specific constituents. The expanding participation of NGOs in the policy process and the premium placed on information and research have "transformed the policy-making playing field," such that new skills are necessary for shaping policy outcomes: "Access, influence and overall policy success are no longer determined solely by traditional power politics, where actors leverage their strength through numbers.... [The new politics] is a politics in which knowledge, ... scientific expertise, triumphs" (Laforest and Orsini, 2005, p. 483). This development worries Laforest and Orsini (2005) because it closes off "political spaces to forms of representation that may be unconventional or deemed too politicized" and, further, because it reframes the policy process as a depoliticized one, in which the only currency is data and information (p. 483). 


\section{RESEARCH HYPOTHESES}

Our study tested six hypotheses drawn from Canadian nonprofit policy literature in order to identify factors that contribute to an NGO embracing policy engagement with provincial government ministries. Laforest and Orsini (2005) predict that with more organizations shifting to an evidence-based approach, research will be increasingly emphasized over public advocacy.

Hypothesis 1: Employment in research related positions will increase the extent of respondents' interaction with government.

Laforest and Orsini (2005), Phillips (2007), Carter (2011), and Mulholland (2010) all note the importance of the horizontality of policy making and the prevalence of network-based decision making. As a result, NGOs that frequently interact with each other will be more active policy participants.

Hypothesis 2: Engagement with other NGOs will lead to greater interaction with government.

Carter (2011) found policy identification to be an important role for NGOs. The identification of issues and policy solutions is a critical task in early policy formulation (Howlett, Perl, \& Ramesh, 2009).

Hypothesis 3: Greater involvement in the early stages of policy development will result in greater interaction with government throughout the policy making process.

Phillips (2007) found that many nonprofit groups deliver programs, but have very little involvement in other aspects of the policy making process or in policy work similar to that conducted by government agencies.

Hypothesis 4: Greater involvement in the program implementation stage will lead to less interaction with government.

Umbrella organizations, according to Carter (2011), "engage in public policy on behalf of their members" (p. 430). Thus, a person's "desire to have more effective involvement in public policy through greater numbers is usually one of the underlying rationales for forming or signing up with an umbrella organization" (p. 430). We expect membership in umbrella NGOs to lead to greater interaction with government.

Hypothesis 5: Respondents working in umbrella NGOs will have greater interaction with government.

Phillips (2007) points to the importance of briefs presented by voluntary organizations to the Health and Human Resources parliamentary committees of the House of Commons. We argue that active briefing presented by NGOs to all levels of government will increase government interaction.

Hypothesis 6: Greater involvement in briefing tasks will increase the extent of interaction with government. 


\section{Evans \& Wellstead (2014)}

\section{RESEARCH METHODS}

To probe the above research questions, we designed an NGO based, 248-variable survey questionnaire (with 38 questions), drawing in part from previous government capacity surveys conducted by Howlett (2009) and Wellstead, Stedman, and Lindquist (2009). Questions addressed the nature and frequency of various tasks, the extent and frequency of respondents' interactions with other policy actors, and their opinions and attitudes about various aspects of policy-making processes. Questions also addressed respondents' education, previous work experiences, on-the-job training experiences, as well as background information pertaining to age and gender.

The survey was delivered to 1,763 policy analysts working in the NGO sector in the Canadian provinces of Ontario, Saskatchewan, and British Columbia. Four policy fields were selected for this survey: environment, health, immigration, and labour.

These provinces and policy sectors were chosen because they represent heterogeneous cases in terms of politics, history, and economic and demographic scale. Ontario, for example, has the largest economy and population of Canada's provinces (13.5 million people and 40\% of Canada's Gross Domestic Product [GDP]). Unlike most other provinces, Ontario has a competitive three-party political system; each party has governed at some point since 1990. British Columbia presents a mid-size province (population 4.4 million; $12 \%$ of national GDP). Provincial elections have been polarized contests between social democrats and a free market coalition that has been housed within various parties. Saskatchewan is a small province (population 1 million; $3 \%$ of national GDP). Its economy is largely based on natural resources and agriculture (Wellstead, 2008). Politics have also been highly polarized, with the provincial government alternating between social democrats and conservatives.

Mailing lists for the survey were compiled, wherever possible, from publicly available sources such as online telephone directories, using keyword searches for terms such as "policy analyst" in job titles or descriptions. In some cases, additional names were added to lists from hard-copy sources, including government organization manuals. Based on preliminary interviews with NGO representatives, we suspected that prospective respondents would undertake a variety of non-policy related tasks. As a result, we also included those who undertook any policy related analysis in their work objectives. Due to the small size of both study populations, a census, rather than a sample, was drawn from each. This method is consistent with other expert-based studies (cf, Laumann \& Knoke, 1987; Zafonte \& Sabatier, 1998).

The authors sent out an unsolicited survey in early 2012 using Survey Monkey, an online commercial software service. A total of 603 returns were collected for a final response rate of 34.4 percent. With the exception of the NGO respondents working in the labour sector, the percentage of respondents in each of the sectors corresponded closely with the identified population developed by the authors. Data was weighted using the iterative proportional fitting or raking method (Center for Disease Control, 2013) and analyzed using SPSS 20.0. Data generated by the survey provided the basis for testing our hypotheses on NGO interaction with government. 
The term non-governmental organization, or NGO, as employed in this study, is defined broadly. This is, in part, because of the challenge of achieving wide agreement on an operational definition. As Lewis (2010) notes, precise "definitions vary as to what constitutes an NGO" (p. 2). As a result, "analyzing the phenomenon of NGOs remains surprisingly difficult. ... Boundaries are unclear. ... This has generated complex debates about what is and what is not an NGO" (Lewis, 2010, p. 2). Moreover, the term is used inconsistently (Anheier and List, 2005, p. 174). Similar definitional challenges confront other related terms, such as third sector (Gidron, 2010, p. 2) and nonprofit (Anheier and List, 2005, p. 180). Consequently, and given the diversity of non-state organizations inhabiting the four policy fields investigated here, we have taken a broadly inclusive approach, defining NGO as "any non-state, not-for-profit ... formed by people in that social sphere. This term is used to describe a wide range of organizations, networks, associations, groups, and movements that are independent of government" (World Health Organization, 2009).

\section{RESULTS AND DATA ANALYSIS}

This section first presents the descriptive results and exploratory factor analysis on the background, work environment, and general perspectives of the respondents. Factor analysis is a method of data reduction that seeks to identify the underlying unobservable (latent) variables reflected in the observed variables (manifest variables). From the descriptive variables thus derived, an ordinary least squares (OLS) regression multivariate analysis explored the drivers of NGO interaction with government officials.

\section{Describing the respondents}

More women $(55.3 \%)$ than men $(44.7 \%)$ responded to the survey, while over half $(52.1 \%)$ of the respondents were over 50 years old. In contrast, only 19.5 percent were under 40 years old. This age distribution is similar to previous policy capacity studies of government agencies (see Howlett, 2009; Wellstead et al., 2010). Respondents were well educated, with 49.4 percent reporting an advanced degree. Over two thirds (67.8\%) had taken at least one policy specific post-secondary course.

Table 1: Tenure with organization

\begin{tabular}{|l|r|r|}
\hline Length of tenure & \multicolumn{1}{|c|}{$\boldsymbol{N}$} & \multicolumn{1}{c|}{ Percent } \\
\hline Less than 1 year & 17 & 3.0 \\
\hline 1-5 years & 196 & 33.7 \\
\hline 6-9 years & 114 & 19.7 \\
\hline 10-14 years & 101 & 17.4 \\
\hline 15-20 years & 64 & 11.0 \\
\hline Greater than 20 years & 89 & 15.3 \\
\hline Total & 581 & 100.0 \\
\hline Missing & & 22 \\
\hline Total & $\mathbf{6 0 3}$ & \\
\hline
\end{tabular}


In Table 1, 43.7 percent reported tenure with their organization of over a decade, and slightly more than a third $(36.7 \%)$ reported tenure of less than five years.

Of the three provinces surveyed, respondents from Ontario represented $44.3 \%$ of the total, followed by British Columbia (35.7\%) and Saskatchewan (19.9\%) (Table 2).

Table 2: Province location

\begin{tabular}{|l|r|r|}
\hline Province & N & Percent \\
\hline British Columbia & 215 & 35.7 \\
\hline Ontario & 267 & 44.3 \\
\hline Saskatchewan & 120 & 19.9 \\
\hline Total & 602 & 100.0 \\
\hline
\end{tabular}

Just over one third (34.3\%) reported that they worked in the health sector, closely followed by the labour sector (30.4\%). Environment-related employment garnered $20.5 \%$, while the immigration sector had the fewest respondents $(14.8 \%)$ (Table 3 ).

Table 3: Policy sector, as identified by respondents

\begin{tabular}{|l|r|r|}
\hline Policy sector & $\mathbf{N}$ & Percent \\
\hline Environment & 123 & 20.5 \\
\hline Health & 207 & 34.3 \\
\hline Immigration & 89 & 14.8 \\
\hline Labour & 183 & 30.4 \\
\hline Total & $\mathbf{6 0 2}$ & $\mathbf{1 0 0 . 0}$ \\
\hline
\end{tabular}

Table 4 lists the types of organizations identified by respondents. Of these, the most frequently mentioned were service delivery NGOs (22.2\%) and government-funded NGOs (20.8\%), followed by trade unions (16.3\%). 
Table 4: NGO organization types

\begin{tabular}{|l|r|r|}
\hline NGO type & Number & Percent \\
\hline Advocacy-based & 106 & 17.3 \\
\hline Government-funded group & 125 & 20.8 \\
\hline Private foundation & 12 & - \\
\hline Industry association & 42 & 6.9 \\
\hline Private foundation & 14 & 2.3 \\
\hline Public foundation & 12 & 2.3 \\
\hline Public education & 68 & 11.2 \\
\hline Research-based & 64 & 10.7 \\
\hline Service delivery based & 133 & 22.2 \\
\hline Think tank & 20 & 3.3 \\
\hline Trade union & 99 & 16.3 \\
\hline Umbrella organization & 68 & 11.3 \\
\hline
\end{tabular}

Note: Total is greater than 100 percent due to multiple choices.

\section{Roles, tasks, and networks}

When asked what perceived role(s) they fulfilled within their organization, just over a third (35.1\%) of respondents identified themselves as directors (Table 5).

Table 5: Role within organization

\begin{tabular}{|l|r|r|}
\hline Role & $\boldsymbol{N}$ & Percent \\
\hline Advisor & 103 & 17.1 \\
\hline Analyst & 48 & 7.9 \\
\hline Communication officer & 71 & 11.7 \\
\hline Co-ordinator & 102 & 17.0 \\
\hline Director & 212 & 35.1 \\
\hline Liaison officer & 33 & 5.5 \\
\hline Manager & 153 & 25.4 \\
\hline Planner & 63 & 10.4 \\
\hline Policy analyst & 101 & 16.8 \\
\hline Researcher & 108 & 17.9 \\
\hline Strategic analyst & 70 & 11.6 \\
\hline Other & 117 & 19.5 \\
\hline
\end{tabular}


The second most commonly mentioned role was that of manager (25.4\%), followed by researcher (17.9\%), coordinator $(17.0 \%)$, and policy analyst $(16.8 \%)$. There was a great deal of overlap between the 11 possible roles respondents could choose from (Cronbach's alpha of .742). Thus, a significant number of respondents saw themselves as fulfilling multidimensional roles within their organization. This is interpreted here as an expression of the necessity for NGO staff to multitask. Furthermore, it can be speculated that the prevalence of multitasking is a reflection of the resource constraints experienced by NGOs. This finding reflects Phillip's (2007) point that NGOs simply do not possess the budgetary capacity to employ staff who specialize exclusively in policy, and that they instead rely on "self-taught" generalists (p. 507). The only exception to this general pattern was found among executive directors, who play a key leadership role within NGOs. Given the demanding managerial and leadership functions required of an executive director, it is understandable that they would uniquely identify themselves in a single role.

\section{Table 6: Involvement in different types of policy work, with factor analysis of four broad categories}

\begin{tabular}{|c|c|c|c|c|c|}
\hline Type of work & $\begin{array}{c}\text { Mean } \\
\text { frequency } \\
\text { (ranking) }\end{array}$ & $\begin{array}{c}\text { Factor } 1 \\
\text { Policy } \\
\text { work } \\
\end{array}$ & $\begin{array}{l}\text { Factor } 2 \\
\text { Briefing }\end{array}$ & $\begin{array}{c}\text { Factor } 3 \\
\text { Networking }\end{array}$ & $\begin{array}{l}\text { Factor } 4 \\
\text { Scientific } \\
\text { research }\end{array}$ \\
\hline Appraise policy options & $3.06(3)$ & .681 & & & \\
\hline Conduct policy-related research & $2.75(5)$ & .652 & & & \\
\hline Evaluate policy processes and procedures & $2.60(8)$ & .746 & & & \\
\hline Evaluate policy results and outcomes & $2.63(7)$ & .839 & & & \\
\hline Identify policy issues & $3.22(2)$ & .848 & & & \\
\hline Identify policy options & $2.94(4)$ & .846 & & & \\
\hline $\begin{array}{l}\text { Brief high-level government decision- } \\
\text { makers }\end{array}$ & $1.76(13)$ & & .800 & & \\
\hline Brief senior management in government & $2.00(12)$ & & .901 & & \\
\hline $\begin{array}{l}\text { Brief low- or mid-level policy managers in } \\
\text { government }\end{array}$ & $2.46(9)$ & & .782 & & \\
\hline Consult with stakeholders & $3.44(1)$ & & & .527 & \\
\hline Implement or deliver policies or programs & $2.70(6)$ & & & .692 & \\
\hline Negotiate with program managers & $2.38(10)$ & & & .839 & \\
\hline $\begin{array}{l}\text { Negotiate with stakeholders on policy } \\
\text { matters }\end{array}$ & $2.32(11)$ & & & .747 & \\
\hline Conduct scientific Research & $1.71(14)$ & & & & .929 \\
\hline
\end{tabular}

Notes: Based on 1-5 scale, where 1=never and 5=weekly. Extraction Method: Principal Component Analysis. Rotation Method: Varimax with Kaiser Normalization. $70.38 \%$ of the variance explained. 
Respondents were asked about their involvement in certain types of policy-related work (on a five point scale, where $1=n e v e r$ and $5=$ weekly). Consulting with shareholders was the most frequent activity among respondents (mean=3.44, with $31.3 \%$ indicating at least monthly involvement) (Table 6). This was followed by relatively rudimentary policy tasks: namely, identifying policy issues (18.0\%), identifying policy options (12.1\%), and appraising policy options (16.1\%), all of which required monthly involvement. A factor analysis of these 14 items (with $70.38 \%$ of the variance explained) produced four distinct broad items, as seen in Table 6: policy work, briefing, networking and scientific research. These variables (also listed in Table 7) were used in the OLS model.

\section{Table 7: Type of policy work undertaken (summed from above factor analysis)}

\begin{tabular}{|l|r|r|}
\hline & $\boldsymbol{N}$ & Mean \\
\hline Policy work & 427 & 2.89 \\
\hline Briefing & 501 & 2.07 \\
\hline Networking & 475 & 2.72 \\
\hline Scientific research & 507 & 1.71 \\
\hline
\end{tabular}

Note: Based on 1-5 scale where $1=$ never and $5=$ weekly

\section{Capacity and levels of engagement}

Frequent or very frequent (weekly) strategizing or co-ordination with other NGO organizations was indicated by 48.7 percent of respondents (Table 8).

\section{Table 8: Co-ordination with other NGOs}

\begin{tabular}{|l|r|r|}
\hline Frequency & $\mathbf{N}$ & Percent \\
\hline Never & 17 & 3.7 \\
\hline Infrequently & 49 & 10.3 \\
\hline Sometimes & 176 & 37.3 \\
\hline Frequently & 133 & 28.3 \\
\hline Very frequently & 96 & 20.4 \\
\hline Total & 471 & 100.0 \\
\hline Missing & & 131 \\
\hline Total & $\mathbf{6 0 2}$ & \\
\hline
\end{tabular}

This indicates a fairly substantial investment toward building policy community coherence. One interpretation is that the NGO actors recognize the value of co-ordinating and designing a shared framing of policy problems and solutions. In support of this coalition-building activity, NGO respondents expressed significant confidence in their capacity to engage in policy matters. In terms of their organization's overall ability to address policy issues, nearly half of the respondents (42.6\%) perceived a high level of capacity (Table 9). 
Table 9: Organization's capacity to address policy issues

\begin{tabular}{|l|r|r|}
\hline Capacity & $\mathbf{N}$ & Percent \\
\hline Very low & 30 & 6.6 \\
\hline Somewhat low & 71 & 15.4 \\
\hline Moderate & 163 & 35.4 \\
\hline Somewhat high & 150 & 32.6 \\
\hline Very high & 46 & 10.0 \\
\hline Total & 460 & 100.0 \\
\hline Missing & & 143 \\
\hline Total & $\mathbf{6 0 3}$ & \\
\hline
\end{tabular}

When pressed for specific organizational commitment to policy work (Table 10), two thirds of respondents indicated that their senior management and/or board were committed to policy-related work (68.7\%).

\section{Table 10: Perceived adequacy of organization's commitment to policy work}

\begin{tabular}{|l|r|r|}
\hline Activities showing commitment to policy work & \multicolumn{1}{|c|}{$\boldsymbol{N}$} & \multicolumn{1}{|c|}{$\begin{array}{c}\text { Adequate/Very } \\
\text { Adequate (\%) }\end{array}$} \\
\hline Executive director and board involvement in policy & 457 & 68.7 \\
\hline NGO involvement in networks & 449 & 56.2 \\
\hline Recruitment of skilled policy staff & 452 & 38.9 \\
\hline Staffing full-time equivalents & 446 & 32.6 \\
\hline Training of policy staff & 453 & 31.8 \\
\hline
\end{tabular}

Over half $(56.2 \%)$ expressed that their organization had strong commitment to policy work in terms of its involvement in NGO networks. However, as far as keeping the organizations effectively staffed, with sufficient in-house policy staff and on-going training in policy-relevant skills, there was a discernible division. Only a third of respondents thought their organization's commitment to staffing or training were adequate. Another third indicated that their organization was not doing enough.

As noted earlier, the central characteristics of new governance theories are collaboration and deliberation between state and non-governmental actors. Responses to our survey suggest that while policy engagement indeed is taking place, it is not particularly robust. This is illustrated in Table 11, with nearly one third of respondents indicating that they had never been invited by government to participate in a formal policy process. Another 26.1 percent reported they were invited, on average, once per year. At the other end of the participation 
spectrum, 22.3 percent were invited to participate in a more rigorous and consistent manner that entailed monthly and quarterly meetings with government. Table 11 also includes "informal" collaboration; in other words, the invitations from government to NGOs to participate in policy through lower profile and more ad hoc processes. Nearly half $(49.8 \%)$ of respondents reported that they are never invited to participate in any form of consultation with government. More than half $(56.4 \%)$ of respondents indicated that formal invitations from government are rare, occur only once per year, or are simply never extended. However, a third $(33.6 \%)$ of respondents said they engage in informal policy meetings on a monthly or quarterly basis; in comparison, only 22.3 percent are invited to formal consultations with government (see Table 11).

\section{Table 11: Invitations from government to NGOs for formal and informal input on policy matters}

\begin{tabular}{|l|r|r|r|r|}
\hline & \multicolumn{2}{|c|}{ Formal } & \multicolumn{2}{c|}{ Informal } \\
\hline & $\mathbf{N}$ & Percent & $\mathbf{N}$ & Percent \\
\hline Never & 146 & 30.3 & 132 & 28.0 \\
\hline Annually & 125 & 26.1 & 103 & 21.8 \\
\hline Semi-annually & 102 & 21.3 & 78 & 16.6 \\
\hline Quarterly & 78 & 16.3 & 96 & 20.4 \\
\hline Monthly & 29 & 6.0 & 62 & 13.2 \\
\hline Total & 480 & 100.0 & 471 & 100.0 \\
\hline Missing & 123 & & 132 & \\
\hline
\end{tabular}

In terms of their interaction with specific types of government representatives, respondents interacted most frequently (monthly or quarterly) with front line staff $(59.4 \%)$, followed by professional government staff $(40.3 \%)$ and middle level managers (33.1\%) (Table 12). NGO interaction with more senior level government officials was less frequent (senior level provincial managers, 21.1 percent; minister or minister's staff, 18.5\%).

Table 12: Level of interaction

\begin{tabular}{|l|r|r|r|r|}
\hline Government representative & $\boldsymbol{N}$ & Mean & Quarterly (\%) & Monthly (\%) \\
\hline Minister or minister's staff & 478 & 2.21 & 11.3 & 7.2 \\
\hline Senior level provincial government management & 472 & 2.30 & 13.6 & 7.5 \\
\hline Middle level provincial government management & 476 & 3.06 & 24.9 & 18.2 \\
\hline Professional government staff & 470 & 3.01 & 20.2 & 20.1 \\
\hline Front line staff & 476 & 3.51 & 23.4 & 36.0 \\
\hline
\end{tabular}

Notes: These variables, when summed, became the dependent variable in the OLS model, below.

Mean score was derived from a 1 to 5 scale where $1=$ never and $5=$ monthly. 
The survey asked respondents to assess what stage of the policy process they were most involved in. Just over a third $(36.2 \%)$ of respondents became involved only after a policy had been developed, in contrast to the 17.1 percent who were actively involved in early policy stages (Table 13$)$. Only a quarter $(25.8 \%)$ were involved in all stages of the government policy process. A small number (10.3\%) were involved only in policy implementation (10.3\%), and 10.6 percent were not involved at all.

\section{Table 13: Stage of government policy process in which respondents} participated most frequently

\begin{tabular}{|l|r|r|}
\hline Stage of policy process & $\boldsymbol{N}$ & Percent \\
\hline All stages & 121 & 25.8 \\
\hline Early stages & 80 & 17.1 \\
\hline Post-formulation stage & 169 & 36.2 \\
\hline Implementation stage & 48 & 10.3 \\
\hline Not at all & 50 & 10.6 \\
\hline Total & 468 & 100.0 \\
\hline Missing & & 135 \\
\hline Total & 603 & \\
\hline
\end{tabular}

\section{OLS model: Multivariate results}

We used an ordinary least squares (OLS) regression to test our six starting hypotheses about NGO interaction with different levels of government (as described in Table 14). This allowed us to examine the simultaneous effects of the dependent variables on NGO interaction with government agencies (Sokal \& Rohlf, 1969). This analysis has a very robust predictive ability, explaining 59.9 percent of the variation in NGO interaction with government agencies. 


\section{Evans \& Wellstead (2014)}

Table 14. Explaining variations in the level of government interaction (OLS model) a. Dependent Variable: Summed interaction with government officials from Table 12.

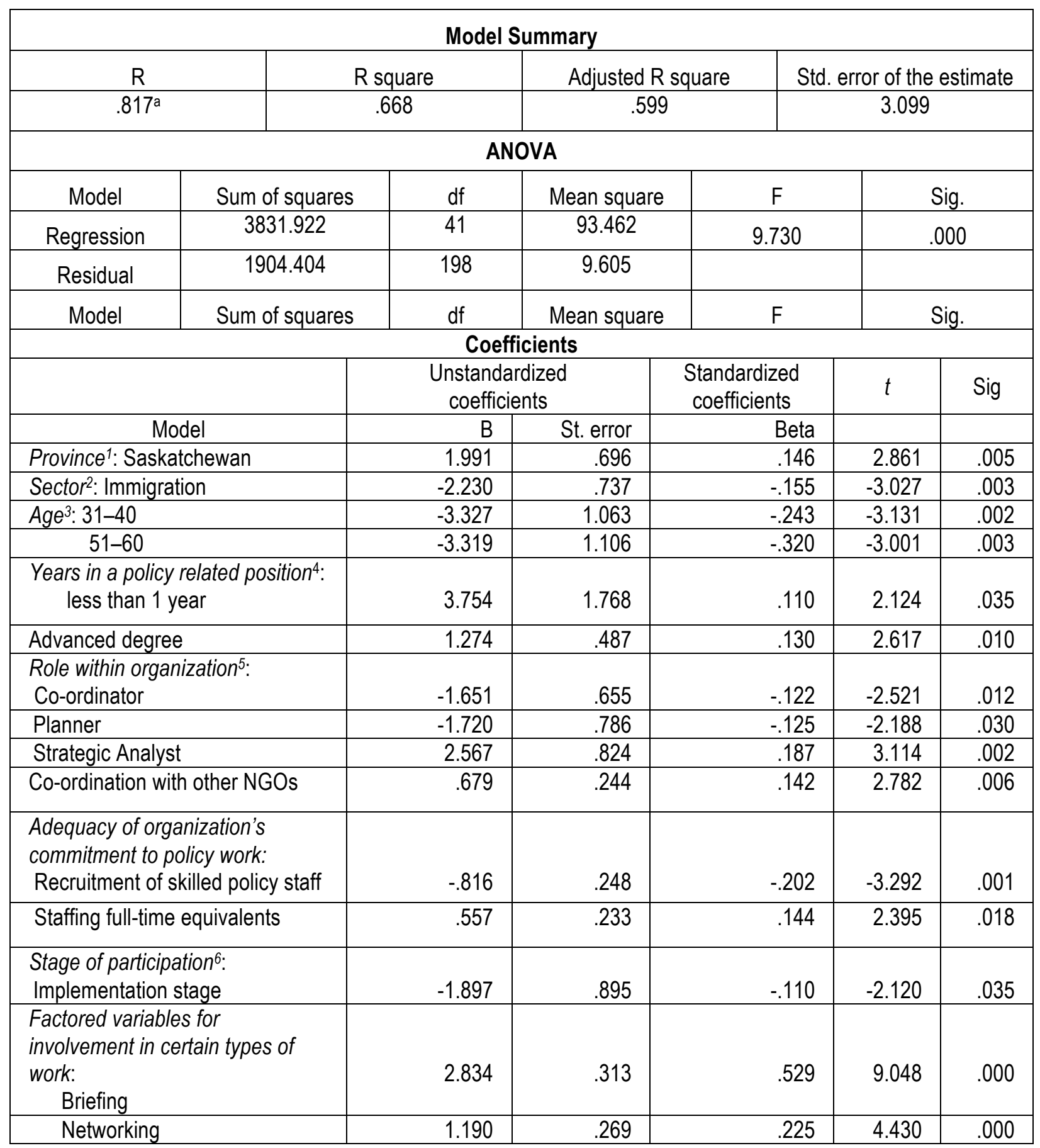

a. Dependent Variable: Summed interaction with government officials from Table 12. 


\section{Evans \& Wellstead (2014)}

\section{HYPOTHESIS TESTING}

The OLS model revealed that research, whether as a self-identified role or as a specific task of the respondent, did not play a role in increasing government interaction. Thus Hypothesis 1 (employment in research-related positions will increase the extent of interaction with government) was rejected. However, the model found that those with co-ordinating and planning responsibilities were less likely to work with government agencies, whereas those who identified themselves as strategic analysts were more likely to. It should be noted that position descriptions vary from organization to organization, and the nature of tasks performed is equally broad.

Hypothesis 2: namely, that co-ordination with other NGOs would lead to a greater level of interaction with government officials-was strongly supported. Networking activities in general also led to greater interaction. The model failed to support Hypothesis 3 _(greater involvement in the post-formulation stage will result in greater interaction with government). Although involvement in the post-formulation stage had no effect on NGO engagement, those who implemented policy were less likely to interact with government officials than those who were involved in the policy process at earlier stages, thus confirming Hypothesis 4 (greater involvement in program implementation stage will lead to less interaction with government).

Membership in umbrella organizations had no effect on the frequency of interaction. Thus, Hypothesis 5 (respondents working in umbrella NGOs will have greater interaction with government) was rejected. In fact, the membership in any type of NGO organization has no influence on interaction. Finally, the frequency of briefing activity was one of the most robust independent variables in the model and therefore supported Hypothesis 6 (greater involvement in briefing tasks will increase the extent of interaction with government).

The OLS model produced number of unanticipated results that fell outside of the six hypotheses. The model found that sector of employment, location, age, and education levels were all important independent variables. Respondents from Saskatchewan and those with advanced university degrees were more likely to engage with government officials. Those working in the immigration sector and those from two age cohorts (ages 31-40 and 51-60) were less likely to be involved.

The very small cohort of respondents who had been with their organization for less than one year were more likely to be engaged with government departments in their work. Two items relating to the adequacy of the organization's commitment to policy work were included adequacy of recruitment of skilled policy staff and staffing full-time equivalents. Both of these items, along with "Executive director and board involvement," "NGO involvement in networks," and "Training of policy staff' (as in Table 10), measure the perceived adequacy of the organization's commitment to policy work. In previous government policy capacity studies, when summed, these five items represent policy capacity. A test for reliability resulted in a Cronbach's alpha of .830, meaning that, when summed, the five variables presented a coherent policy capacity. However, in the above OLS model, the decline in government involvement was, in part, explained by the recruitment of skilled policy staff. This was in contrast to when respondents indicated that their organization was doing a good job of staffing full-time equivalents. 


\section{Evans \& Wellstead (2014)}

\section{DISCUSSION AND IMPLICATIONS FOR GOVERNANCE AND POLICY MAKING}

If the question is, "Do non-government actors play a significant role in the policy process?" then the answer, according to our data analysis, would be, "Sometimes yes and sometimes no." At least, that appears to be the case in the three Canadian provinces surveyed here. More generally, new governance visions of an inclusive, pluralist policy process providing space for non-governmental actors are neither totally accurate nor inaccurate. Both proponents and critics can draw from the data presented here to support their positions. Consequently, we must be more nuanced than categorical in our analysis, as we proceed to examine the means by which policy engagement takes place. New governance-type arrangements may well be evolving, and may be doing so unevenly.

The Canadian analysis indicates an imbalance, both in the capacity of non-governmental actors to engage effectively in policy processes and in their opportunities to actually do so. A stark example of this is that nearly a third of respondents indicated that they had never been invited to participate in any policy discussion with their provincial government. This corroborates Carter's (2011) finding that less than a quarter of nonprofits are able to participate in the policy process. This trend is troubling and certainly provides reason to question the actual extent of engagement. However, in contrast, an equal number of our respondents report fairly frequent (monthly or quarterly) engagement with their provincial government, which is indicative of robust multi-actor policy processes of some type. We need to learn more about why those NGOs at each of these extremes are so significantly or insignificantly engaged.

Several researchers have identified the constrained policy capacity of non-governmental organizations as the key reason for modest or even non-participation in the policy process (Phillips, 2007; Carter, 2011; Mulholland, 2010). Yet just over half of the respondents to our survey considered the policy capacity of their organization to be "somewhat high" or "very high." At the same time, our survey data indicate that non-governmental actors have relatively serious concerns about the on-going policy training of staff, as well as the recruitment of sufficient numbers of staff with policy expertise. This does not necessarily support Laforest and Orsini's (2007) overarching claim that voluntary sector organizations are "investing most of their energy in research and evidence-based advocacy" (p. 482). But it does tend to support their argument that "access, influence and overall policy success are no longer determined solely by traditional power politics. ... [The new politics] is a politics in which knowledge ... triumphs" (Laforest \& Orsini, 2005, p. 483).

Non-governmental actors understand this. What is less clear is whether it is true that this turn to policy-centred work is replacing other forms of representation. Effective policy advocacy often requires a broad coalition of actors working in a co-ordinated manner. Our data analysis demonstrates that more frequent co-ordination between NGOs is associated with more frequent interaction with government. The obvious interpretation is that the co-ordination of NGOs within a policy field maybe a requisite step for deliberation with government. Paradoxically, despite the importance of policy work, our study did not support the hypothesis that research positions would increase interaction with government officials. From this finding, future research should examine how NGO policy networks and coalitions leverage a variety of resources, both policy-related and political, that would facilitate government responsiveness. The success of networked NGOs may also lie in their ability to produce the evidence, which Laforest and Orsini (2005) claim governments demand. The data presented here 
indicates networked NGOs expand their capacity to produce research valued by governments. Original, policy relevant research becomes the means to gain a hearing at the government policy table.

A critical consideration that tests the integrity of new governance understandings of the policy process is the stage at which non-governmental actors are invited to participate. For governments, developing a policy proposal from the initial problem framing (the identification of a collective problem) to implementation (establishing a functioning program on the ground) requires the government to determine how that program will be delivered and by whom. In the Canadian context this typically means the NGO role "becomes one of program delivery" (Carter, 2011, p. 432). We assumed that the ideal point of engagement would begin at the earliest stages of the policy making process, when policy is still being formulated and before any concrete directions or details are decided. Engagement at this early stage would indicate a genuine sharing of decisionmaking on critical aspects of policy. Our data indicate a nearly even split between those invited to participate at the early stages of policy development (or all stages) and those who were invited to participate only in the postformulation or implementation stages. We observe what Howlett et al. (2014) refer to as a significant "lumpiness"-that is, a significant degree of engagement during the early stages of the process, as well as a significant degree of engagement restricted to the operational end. The fact that the process is not characterized by frequent interaction raises questions about the robustness of the policy process. Are these encounters merely perfunctory, allowing government to "check the box" on consultation?

We cannot conclude, based on our data, that the precepts of new governance theory are wholly inapplicable to our three Canadian cases, but we might characterize them, where they do apply, as "shallow." In practice, new governance theory precepts are more ad hoc than embedded and institutionalized as policy praxis. If governments are serious about opening the policy process up to non-governmental actors, then some greater institutionalization of the process is necessary. As it stands, governments may or may not engage other policy actors, and if they do so, the effect may vary widely, from inconsequential to substantial. Creating new, formal mechanisms for sustained policy engagement would remedy the ad hoc and perfunctory aspects of the existing model. These could take the form of advisory councils composed of both government and non-government policy actors operating in a specific policy domain and mandated to engage in questions of policy design and implementation. Constructing such new councils would serve several substantive purposes. First, if sufficiently resourced, they might address NGOs' uneven capacity to engage in research and policy advocacy. Second, the very existence of such councils might require government to engage with non-state actors in a routine way. And third, non-governmental policy actors might give greater priority to cross-organizational co-ordination and strategizing in preparation for advisory council meetings.

\section{ACKNOWLEDGEMENTS}

The authors wish to gratefully acknowledge the Social Sciences and Humanities Research Council of Canada for generously funding this research. We also would like to acknowledge the assistance provided by Halina Sapeha. 


\section{Evans \& Wellstead (2014)}

\section{NOTES}

1. Reference category: Ontario

2. Reference category: Health

3. Reference category: 30 or younger

4. Reference category: $>20$ years (Number of years in total in a policy related position)

5. Reference category: Director

6. Reference category: At all stages

\section{REFERENCES}

Anderson, G. (1996). The new focus on the policy capacity of the federal government. Canadian Public Administration 39(4), 469-488.

Anheier, H., \& List, R. (2005). A dictionary of civil society, philanthropy, and the non- profit sector. London: Routledge.

Ansell, C., \& Gash, A. (2008). Collaborative governance in theory and practice. Journal of Public Administration Research and Theory, 18(4), 543-571.

Bernier, L., Howlett, M. (2011). The analysis capability of the policies of the Quebec government: Survey results by Quebec officials. Canadian Public Administration, 54, 143-152.

Bevir, M. (2011). Governance as theory, practice, and dilemma. In Mark Bevir (Ed.), The SAGE Handbook of Governance. London: SAGE Publishing.

Bevir, M., \& Rhodes, R.A.W. (2003). Interpreting British government. London: Routledge.

Bode, I. (2006). Disorganized welfare mixes: Voluntary agencies and new governance regimes in Western Europe. Journal of European Social Policy, 16, 346-359.

Capano, G. (2011). Government continues to do its job: A comparative study of governance shifts in the higher education sector. Public Administration, 89(4), 1622-1642.

Carter, S. (2011). Public policy and the nonprofit sector. The Philanthropist, 23(4), 427-435.

Center for Disease Control. (2013). Fact sheet: Improving survey methodology. Atlanta, Georgia: Division of Behavioral Surveillance.

Edelenbos, J. (1999). Design and management of participatory policy making. Public Management Review, $1(4), 569-578$.

Eversole, R. (2010). Remaking participation. Community Development Journal, 47(1), 29-41.

Fellegi, I. (1996). Strengthening our policy capacity. Report of the deputy minister's task force. Ottawa: Supply and Services Canada.

Ford, C., \& Condon, M. (2011). New governance and the business organization. Law \& Policy, 33(4), 449-458.

Gidron, B. (2010). Third Sector: Definition. In Helmut K. Anheier \& Stefan Toepler (Eds.), International Encyclopedia of Civil Society. (1550-1553). Springer International Publishing.

Goetz, K. (2008). Governance as path to government. West European Politics, 31(1-2), 258-279.

Gunningham, N. (2009). The new collaborative governance: The localization of regulation. Journal of Law and Society, 36(1), 145-166.

Heritier, A., \& Lehmkuhl, D. (Eds.). (2008). The shadow of hierarchy and new modes of governance. Journal of Public Policy, 28(1), 1-17. 


\section{Evans \& Wellstead (2014)}

Hill, J.C., \& Lynn Jr., L.E. (2005). Is hierarchical governance in decline? Evidence from empirical research. Journal of Public Administration Research and Theory, 15(2), 173-195.

Hoffmann, M. (2011). Climate governance at the crossroads. Oxford: Oxford University Press.

Hooghe, L., \& Marks, G. (2003). Unravelling the central state, but how? Types of multi-level governance. American Political Science Review, 97(2), 233-243.

Howlett, M. (2002). Policy development. In C. Dunn (Ed.), The handbook of Canadian public administration (pp. 173-191). Toronto, ON: Oxford University Press.

Howlett, M. (2009). Policy analytical capacity and evidence-based policy-making: Lessons from Canada. Canadian Public Administration, 52(2), 153-175.

Howlett, M., Perl, A., \& Ramesh, M. (2009). Studying public policy: Policy cycles and policy subsystems, Third edition. Toronto, ON: Oxford University Press.

Howlett, M., Rayner, J., Tollefson, C., (2009). From government to governance in forest planning? Lessons from the case of the British Columbia Great Bear Rainforest initiative. Forest Policy and Economics 11, 383-391.

Howlett, M., \& Wellstead, A. (2012). Policy work in multi-level states: Institutional autonomy and task allocation among Canadian policy analysts. Canadian Journal of Political Science, 45(4), 757-780.

Howlett, M., Tan, S. Migone, A., Wellstead, A., \& B. Evans. (2014). Policy Formulation and the Tools of Policy Appraisal: The Distribution of Analytical Techniques in Policy Advisory Systems. Public Policy and Administration, 29(4), 271-291.

Janicke, M., \& Jorgens, H. (2006). New approaches to environmental governance. In Janicke, Martin, Jacobs, \& Klaus (Eds.), Environmental Governance in Global Perspective. Berlin: Freie Universität.

Koch, P. (2013). Overestimating the shift from government to governance: Evidence from Swiss metropolitan areas. Governance: An International Journal of Policy, Administration, and Institutions, 26(3), 397-423.

Laforest, R., \& Orsini, M. (2005). Evidence-based engagement in the voluntary sector: Lessons from Canada. Social Policy and Administration, 39(5), 481-497.

Laumann, E., \& Knoke, D. (1987). The organizational state: Social choice in national policy domains. Madison, Wisconsin: University of Wisconsin Press.

Lewis, D. (2010). "Nongovernmental Organizations: Definitions and History." In International Encyclopedia of Civil Society. Springer, Science and Business , XXVI, pp. 1056-1062.

Lindquist, E. (2009). There's more to policy than alignment. CPRN Research Report. Ottawa: Canadian Policy Research Networks Inc. http://www.cprn.org/documents/51384_EN.pdf

Lobel, O. (2004). The renew deal: The fall of regulation and the rise of governance in contemporary legal thought. Minnesota Law Review, 89(2), 263-293.

Mol, A. (2007). Bringing the environmental state back in. In P. Glasbergen, F. Biermann, \& A. Mol (Eds.), Partnerships, governance and sustainable development (pp. 214-236). Cheltenham: Edward Elgar.

Mulholland, E. (2010). New ways to keep up our end of the policy conversation. The Philanthropist, 23(2), 140-145.

NeJaime, D. (2009). When new governance fails. Ohio State Law Journal, 70(2), 323-399.

Noveck, B. (2011). The single point of failure. In S. Van der Hof \& M. Groothuis (Eds.), Innovating government (pp. 77-99). The Hague: Asser Press.

Peters, B.G. (1996). The policy capacity of government. Research paper no. 18, Canadian Center for Management Development. URL: http://csps-efpc.gc.ca/Research/publications/pdfs/p62e.pdf [December 27, 2007]. 


\section{Evans \& Wellstead (2014)}

Phillips, S.D. (2007). Policy analysis and the voluntary sector: Evolving policy styles. In L. Dobuzinskis, M. Howlett, \& D. Laycock (Eds.), Policy analysis in Canada: The state of the art (pp. 497-522). Toronto: University of Toronto Press.

Rasmussen, K. (1999). Policy capacity in Saskatchewan: Strengthening the equilibrium. Canadian Public Administration 42(3), 331-338.

Rhodes, R.A.W. (1996). The new governance: Governing without government. Political Studies, xliv, 652-667.

Savoie, D. (2003). Strengthening the policy capacity of government. Report to the panel on the role of government. Research Paper Series, 1, 239-290.

Sokal, R.R., \& Rohlf, F.J. (1969). Regression. Biometry 169, 404-493. San Francisco: WH Freeman and Co.

Solomon, J. (2008). Law and governance in the $21^{\text {st }}$ century regulatory state. Texas Law Review, 86, 819-856. van der Heijden, J. (2013). Looking forward and sideways: Trajectories of new governance theory. Amsterdam Law School Legal Studies Research Paper no. 2013-2014.

van der Heijden, J., \& Ten Heuvelhof, E. (2012). The mechanics of virtue. Environmental Policy and Governance, 22(3), 177-188.

Voyer, J. (2007). Policy analysis in the federal government: Building the forward-looking policy research capacity. In L. Dobuzinskis, M. Howlett, \& D. Laycock (Eds.), Policy analysis in Canada: The state of the art (pp. 123-131). Toronto, ON: University of Toronto Press.

Wellstead, A. (2008). The (post) staples economy and the (post) staples state in historical perspective. In M. Howlett \& K. Brownsey (Eds.). Canada's resource economy in transition: The past, present, and future of Canadian staples industries (pp. 19-34). Toronto: Emond Montgomery Publications.

Wellstead, A., \& Stedman, R. (2010). Policy capacity and incapacity in Canada's federal government: The intersection of policy analysis and street level bureaucracy. Public Management Review, 12(6), 893-910.

Wellstead, A., \& Stedman, R. (2011). Climate change policy capacity at the sub-national government level. Journal of Comparative Policy Analysis: Research and Practice, 13(5), 461-478.

Wellstead, A., Stedman, R., \& Howlett, M. (2011). Multi-level policy analytical capacity in Canada: A structural equation model (SEM) study of federal, provincial and territorial policy analysts and analysis. Public Policy and Administration, 26(3), 353-373.

Wellstead, A., Stedman, R., \& Lindquist, E. (2009). The nature of regional policy work in Canada's federal public service. Canadian Political Science Review, 3(1), 34-56. World Health Organization. URL: http://www.who.int/trade/glossary/story006/en [May 15, 2014].

Zafonte, M., \& Sabatier, P. (1998). Shared beliefs and imposed interdependencies as determinants of ally networks in overlapping subsystems. Journal of Theoretical Politics, 10(4), 473-505.

\section{ABOUT THE AUTHORS / LES AUTEURS}

Bryan Evans is Associate Professor in the Department of Politics and Public Administration at Ryerson University, Toronto, Canada. Email: b1evans@politics.ryerson.ca .

Adam Wellstead is Assistant Professor of Environmental and Energy Policy, Department of Social Sciences, Michigan Technological University, Michigan, USA. Email: awellste@mtu.edu . 